\title{
PENGARUH INTERGOVERNMENTAL REVENUE, KEKAYAAN PEMERINTAH DAERAH DAN UMUR PEMERINTAH DAERAH TERHADAP TINGKAT PENGUNGKAPAN LAPORAN KEUANGAN PEMERINTAH DAERAH (Survei pada Pemerintah Kabupaten/Kota di Sulawesi Tengah)
}

\author{
Rafida1, Ridwan $^{2}$, M. Ikbal Abdullah², Nina Yusnita Yamin'2 \\ ${ }^{1}$ Mahasiswa Jurusan Akuntansi Fakultas Ekonomi Universitas Tadulako Palu \\ 2Dosen Jurusan Akuntansi Fakultas Ekonomi Universitas Tadulako Palu
}

\begin{abstract}
This study aims to analyze the effect of intergovernmental revenue, wealth of local government, and local government age to local government financial statement disclosure in Central Sulawesi. The analysis method used in this study is a multiple linear regression analysis. The results showed that intergovernmental revenue, local government wealth, and age of local government have a significant effect to the disclosure level of local government financial statements simultaneously. Intergovernmental revenue has a significant negative effect to the disclosure level of local government financial statements, while the wealth of local government and the age of local governments have no significant effect to the disclosure level of local government financial statements partially.
\end{abstract}

Keywords: Intergovernmental Revenue, Wealth of Local Government, Local Government Age, Disclosure Level of Local Government Financial Statements

\begin{abstract}
ABSTRAK
Penelitian ini bertujuan untuk menganalisis pengaruh intergovernmental revenue, kekayaan pemerintah daerah, dan umur pemeintah daerah terhadap tingkat pengungkapan laporan keuangan pemerintah daerah di Sulawesi Tengah. Metode yang digunakan dalam penelitian ini yaitu analisis regresi linear berganda. Hasil penelitian menunjukan bahwa secara simultan intergovernmental revenue, kekayaan pemerintah daerah, dan umur pemerintah daerah berpengaruh signifikan terhadap tingkat pengungkapan laporan keuangan pemerintah daerah. Intergovernmental revenue berpengaruh negatif dan signifikan terhadap tingkat pengungkapan laporan keuangan pemerintah daerah, sedangkan kekayaan pemerintah daerah dan umur pemerintah daerah terbukti tidak berpengaruh signifikan terhadap tingkat pengungkapan laporan keuangan pemerintah daerah.
\end{abstract}

Kata Kunci: Intergovernmental Revenue, Kekayaan Pemerintah Daerah, Umur Pemeintah Daerah, Tingkat Pengungkapan Laporan Keuangan Pemerintah Daerah

\author{
Jurnal Akun Nabelo: \\ Jurnal Akuntansi Netral, Akuntabel, Objektif \\ Volume 1/Nomor 2/Jan 2019 \\ Jurusan Akuntansi FEB-Universitas Tadulako
}

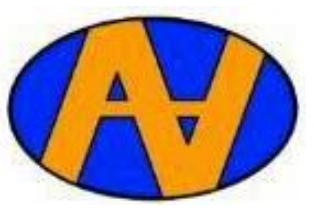




\section{A. PENDahuluan}

Pengelolaan keuangan yang andal, transparan, dan akuntabel wajib dilaksanakan oleh pemerintah, baik pusat maupun daerah. Kewajiban ini diatur pada Undang-Undang Nomor 23 Tahun 2004 tentang Pemerintahan Daerah. Regulasi tersebut secara lugas menguraikan peralihan sebagian urusan pemerintah pusat ke pemerintah daerah. Peralihan ini tentunya juga akan berimplikasi pada beberapa kebijakan diantaranya, desentralisasi fiskal dan reformasi keuangan. Perubahan secara substansi dilakukan pada seluruh tahapan atau siklus pengelolaan keuangan yang berawal dari tahap perencanaan, perumusan anggaran, perealisasian anggaran, pertanggungjawaban, dan pelaporan keuangan.

Reformasi keuangan, khususnya di pemerintah daerah erat kaitannya dengan good government governance yang berorientasi pada pencapaian tujuan nasional serta pemerintahan yang dalam pencapaian tujuan nasional tersebut dilakukan secara efektif dan efisien (Halim \& Iqbal, 2012). Dengan demikian, setiap aktivitas organisasi publik dapat dipertanggungjawabkan, terutama secara finansial (Halim \& Iqbal, 2012).

Sebagai suatu bentuk mekanisme pertanggungjawaban atas pengelolaan keuangan negara, laporan keuangan pemerintah, termasuk pemerintah daerah, harus diaudit. Sebab laporan keuangan merupakan bahan pertimbangan bagi stakeholder dalam membuat keputusan. Oleh karena itu, laporan keuangan seharusnya didukung dengan pengungkapan yang cukup dan memadai. Dengan kata lain, pengungkapan yang tertuang dalam Catatan Atas Laporan Keuangan (CALK) akan mencerminkan kualitas laporan keuangan.

Standar Akuntansi Pemerintahan (SAP) merupakan pedoman yang digunakan oleh setiap entitas pemerintah daerah dalam melaksanakan akuntansi dan menyusun laporan keuangan pemerintah daerah. Peraturan Pemerintah Nomor 71 Tahun 2010 merupakan regulasi resmi yang memuat mengenai SAP dengan tujuan untuk memberikan jaminan agar pemerintah daerah konsisten dalam pelaporan keuangan. Semua itu bagian dari upaya untuk mewujudkan transparansi dan akuntabilitas tata kelola pemerintahan yang baik.

Prinsip pengungkapan penuh (full disclosure) merupakan salah satu prinsip akuntansi dalam pelaporan keuangan yang substansinya memuat informasi dalam laporan keuangan secara lengkap. Informasi keuangan tersebut tersajikan dalam laporan keuangan yang tampak pada halaman depan dan informasi yang dapat dilihat dalam CALK yang menguraikan dan menjelaskan item-item yang diungkapkan dalam laporan keuangan. Hal ini bermakna bahwa CALK merupakan satu kesatuan dari laporan keuangan itu sendiri.

Secara empiris, pengungkapan informasi dalam laporan keuangan belum menunjukkan hasil yang memadai sebagaimana hasil penelitian Setyaningrum (2016) yang mengungkap bahwa tingkat pengungkapan laporan keuangan oleh pemerintah daerah rata-rata hanya mencapai nilai 52,09\%. Hasil tersebut senada dengan temuan Hilmi \& Martani (2012) yang menunjukkan rata-rata tingkat pengungkapan pada CALK hanya mencapai nilai 44,56\%. Hasil tersebut menunjukkan bahwa tingkat pengungkapan laporan keuangan pemerintah daerah (LKPD) masih tergolong rendah yang mana berimplikasi pada "wajah" kualitas LKPD yang masih rendah pula. Maka dari itu, penelitian ini bertujuan menyelidiki faktor-faktor yang dapat mempengaruhi tingkat pengungkapan LKPD dengan sampel adalah pemerintah kabupaten/kota di Provinsi Sulawesi Tengah.

\section{B. TELAAH LITERATUR}

Kualitas laporan keuangan, salah satunya ditunjukkan dari CALK. 

Rafida, Ridwan, Abdullah, \& Yamin

Semakin penuh informasi yang tersajikan dalam pengungkapannya, maka semakin berkualitas laporan keuangannya. Bukankah informasi tersebut akan digunakan oleh berbagai stakeholders untuk mengambil keputusan? Sebagaimana yang dijelaskan dalam teori signaling bahwa informasi yang diungkapkan oleh entitas kepada pihak eksternal lebih didorong karena adanya informasi tidak simetris antara pihak manajemen dan pihak eksternal. Untuk mereduksi atau setidaknya meminimalkan ketidaksimestrisan informasi tersebut maka perlu adanya pengungkapan, baik berupa informasi keuangan maupun non keuangan.

Pengungkapan dalam CALK merupakan informasi atau sinyal dari entitas, dalam hal ini pemerintah sebagai pengemban amanah, yang tentunya akan berusaha untuk memberikan sinyal kepada masyarakat. Pemberian sinyal ini bertujuan agar supaya masyarakat mengetahui kinerja pemerintah. Selain itu, kepercayaan dan dukungan kepada pemerintah menjadi bagian dari tata kelola pemerintahan.

Sinyal yang baik dapat diperoleh melalui informasi yang termuat pada laporan keuangan yang bermutu, sistem pengawasan internal yang memadai, pengungkapan yang lengkap, dan penjelasan yang lebih rinci. Informasi tersebut dapat diberikan melalui berbagai cara diantaranya melalui website. Penyampaian informasi keuangan pemerintah daerah tersebut juga merupakan bagian dari pelaksanaan akuntabilitas publik dan dilakukan secara transparan. Sebagaimana yang dikemukakan oleh Puspita \& Martani (2012) bahwa LKPD secara lebih optimal untuk menunjukkan telah dilaksanakan amanat yang diberikan oleh masyarakat kepada pemerintah.

Pengungkapan informasi mengenai peristiwa ekonomi yang berdampak terhadap kinerja operasi entitas seharusnya lengkap dan jelas. Selain itu, pengungkapan informasi seharusnya tidak membingungkan pengguna laporan keuangan sehingga memudahkan pengguna dalam merumuskan keputusan ekonomis (Ghozali \& Chariri, 2001).

Hasil penelitian Setyaningrum \& Syafitri (2012) menunjukkan bahwa intergovernmental revenue, kekayaan yang dimiliki pemerintah daerah, dan umur pemerintah daerah berpengaruh signifikan terhadap tingkat pengungkapan LKPD. Begitu pula dengan hasil penelitian Setyowati (2016) yang menemukan bahwa terdapat pengaruh signifikan pada intergovernmental revenue, kekayaan yang dimiliki pemerintah daerah, dan umur pemerintah daerah terhadap tingkat pengungkapan LKPD. Merujuk hasil tersebut, maka peneliti merumuskan hipotesis sebagai berikut:

H1: Intergovernmental revenue, kekayaan pemerintah daerah, dan umur pemerintah daerah berpengaruh secara signifikan terhadap tingkat pengungkapan LKPD.

Sumber pendanaan pada Anggaran Pendapatan dan Belanja Daerah (APBD) salah satunya bersumber dari Dana Perimbangan atau intergovernmental revenue. Dana perimbangan merupakan alokasi dana bagi hasil yang meliputi Dana Alokasi Umum (DAU) dan Dana Alokasi Khusus (DAK) yang mana keduanya bersumber dari pendapatan pemerintah pusat dalam rangka pelaksanaan desentralisasi. Pengelolaan dan pertanggungjawaban Dana Perimbangan tersebut harus sesuai dengan ketentuan yang berlaku.

Setyoningrum mengungkap bahwa tidak terdapat pengaruh signifikan pada intergovernmental revenue terhadap tingkat pengungkapan LKPD. Sementara, Setyaningrum \& Syafitri (2012) menemukan bahwa intergovernmental revenue, yang diproksikan dengan rasio Dana Perimbangan terhadap total pendapatan, berpengaruh negatif terhadap tingkat pengungkapan 
LKPD. Hasil tersebut berbeda dengan temuan Suhardjanto \& Lesmana (2010) yang menemukan bahwa pendapatan transfer berpengaruh positif terhadap pengungkapan wajib pada LKPD. Ketidakkonsistenan temuan tersebut memberikan indikasi adanya gap dan menjadi alasan untuk dilakukan pengujian kembali. Maka hipotesis yang dirumuskan adalah sebagai berikut:

H2: Intergovernmental revenue berpengaruh secara signifikan terhadap tingkat pengungkapan LKPD.

Kekayaan daerah dapat diukur atas dasar pendapatan yang diterima daerah dalam kegiatan memcukupi kebutuhan dan mencapai kemakmuran daerah. Kekayaan yang dimiliki pemerintah daerah mempunyai hubungan positif dengan peningkatan pengungkapan LKPD karena kekayaan daerah merupakan sinyal mengenai kualitas manajemen (Hilmi \& Martani, 2012). Dengan kata lain, semakin besar kekayaan daerah maka menunjukkan sinyal yang baik mengenai kualitas manajemen yang baik dalam hal ini pemerintah daerah.

Beberapa penelitian yang dilakukan menunjukkan bahwa kekayaan pemerintah daerah memberikan pengaruh positif terhadap tingkat pengungkapan LKPD (Hilmi \& Martani, 2012; Setyowati, 2011). Maka, hipotesis adalah:

H3: Kekayaan pemerintah daerah berpengaruh secara signifikan terhadap tingkat pengungkapan LKPD.

Umur suatu entitas menunjukkan sudah berapa lama entitas tersebut beroperasi sejak pendiriannya (Setyaningrum \& Syafitri, 2012). Pada konteks pemerintah daerah, umur administrative pemerintah daerah diproksikan dilihat berdasarkan undang-undang yang mengatur tentang pembentukan daerah tersebut (Suhardjanto \& Lesmana, 2010). Asumsi dasar yang mendasari digunakannya variabel umur pemerintah daerah adalah bahwa semakin bertambah umur, maka pemerintah daerah tersebut semakin berkembang, maju, dan berpengalaman. Hasil penelitian Suhardjanto \& Lesmana (2010) menunjukkan bahwa umur suatu pemerintah daerah menunjukkan pengalaman pemerintah daerah tersebut dalam mengoperasikan sistem administrasi keuangan dan ketaatan pemerintah daerah tersebut terhadap ketentuan peraturan yang berlaku.

Walliyani \& Mahmud (2015) dalam penelitiannya menemukan bahwa umur pemerintah daerah berpengaruh positif signfikan terhadap tingkat pengungkapan LKPD. Sementara, Laupe (2017) menemukan bahwa umur pemerintah daerah tidak berpengaruh signfikan terhadap tingkat kepatuhan pemerintah daerah terhadap pengungkapan wajib pada LKPD. Oleh karena itu, hipotesis dirumuskan sebagai berikut:

H4: Umur pemerintah daerah berpengaruh secara signifikan terhadap tingkat pengungkapan LKPD.

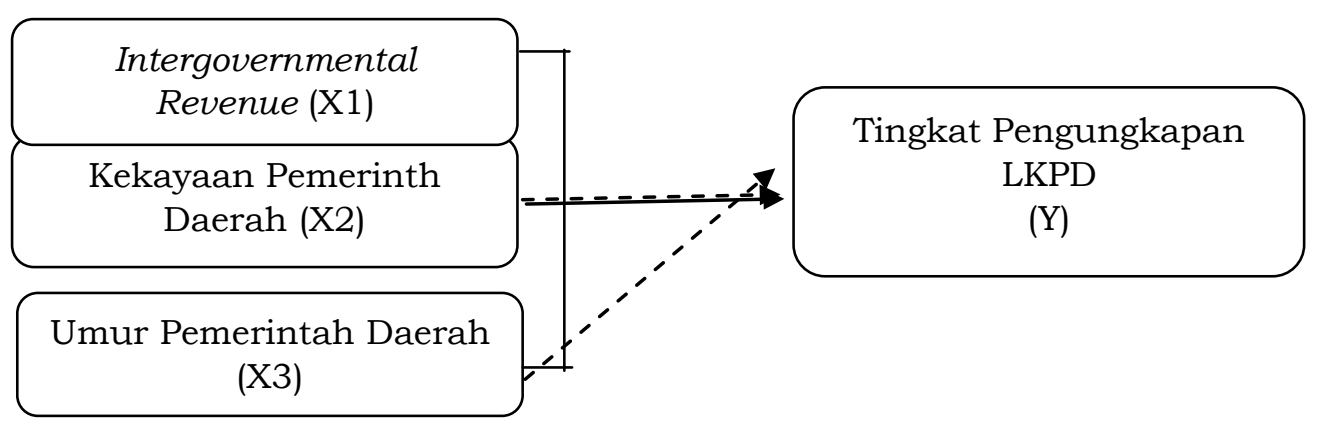

Sumber: Data diolah peneliti, 2018 

Rafida, Ridwan, Abdullah, \& Yamin

\section{METODE PENELITIAN}

Penelitian ini merupakan penelitian kuantitatif yang menggunakan analisis regresi linier berganda sebagai alat analisis. Populasi penelitian ini meliputi seluruh pemerintah kabupaten/kota yang ada di Provinsi Sulawesi Tengah. Adapun periode penelitian meliputi tahun 2014 sampai dengan 2016. Seluruh populasi menjadi sampel yang disebut dengan sampel jenuh (sensus). Penelitian ini memiliki 39 observasian data yang berasal dari laporan keuangan 12 pemerintah kabupaten dan satu pemerintah kota di Provinsi Sulawesi Tengah pada masingmasing periode 2014, 2015, dan 2016. Tahapan analisis data pada penelitian ini meliputi pengujian

Tabel 1

Hasil Uji F

ANOVA $^{a}$

\begin{tabular}{|l|r|r|r|r|l|}
\hline Model & $\begin{array}{r}\text { Sum of } \\
\text { Squares }\end{array}$ & df & Mean Square & F & Sig. \\
\hline Regression &, 074 & 3 &, 025 & 7,143 &, $001^{\text {b }}$ \\
1 Residual &, 122 & 35 &, 003 & & \\
Total &, 196 & 38 & & & \\
\hline
\end{tabular}

a. Dependent Variable: Y

b. Predictors: (Constant), LnX3, LnX2, X1

Sumber: Output SPSS, 2018

Tabel 2

Hasil Uji t

Coefficients $^{a}$

\begin{tabular}{|l|r|r|r|r|r|}
\hline \multirow{2}{*}{ Model } & \multicolumn{2}{|c|}{$\begin{array}{c}\text { Unstandardized } \\
\text { Coefficients }\end{array}$} & \multicolumn{1}{|c|}{$\begin{array}{c}\text { Standardiz } \\
\text { ed } \\
\text { Coefficients }\end{array}$} & \multirow{2}{*}{$\mathrm{T}$} & \multirow{2}{*}{ Sig. } \\
\cline { 2 - 4 } & \multicolumn{1}{|c|}{ B } & Std. Error & \multicolumn{1}{|c|}{ Beta } & & \\
\hline (Constant) &, 729 &, 360 & & 2,025 &, 051 \\
X1 &,- 734 &, 193 &,- 560 & $-3,814$ &, 001 \\
LnX2 &, 027 &, 024 &, 153 & 1,117 &, 272 \\
LnX3 &, 009 &, 009 &, 148 & 1,036 &, 307 \\
\hline
\end{tabular}

Dependent Variable: Y

Sumber: Output SPSS, 2018

Tabel di atas menujukkan bahwa persamaan regresi linier berganda yang menggambarkan pengaruh intergovernmental revenue, kekayaan yang dimiliki pemerintah daerah, dan umur administrasi pemerintah daerah terhadap tingkat pengungkapan pada LKPD adalah sebagai berikut: hipotesis dengan uji simultan dan uji parsial.

\section{HASIL DAN PEMBAHASAN}

\section{D.1. Hasil Pengujian Hipotesis}

Hasil pengujian statistik pada tabel 1 menunjukkan bahwa nilai signifikansi yang diperoleh adalah 0,001 yang mana kurang dari tingkat signifikansi 0,05 . Hasil ini bermakna bahwa intergovernmental revenue, kekayaan yang dimiliki pemerintah daerah melalui pendapatan daerah, dan umur administrasi pemerintah daerah bersama-sama berpengaruh signifikan terhadap tingkat pengungkapan pada LKPD. asumsi klasik dan pengujian 
pada LKPD. Sementara, tabel 2 juga menunjukkan variabel kekayaan yang dimiliki pemerintah daerah memiliki tingkat probabilitas signifikansi di atas 0,05 yang berarti bahwa kekayaan yang dimiliki pemerintah daerah tidak berpengaruh signifikan terhadap tingkat pengungkapan LKPD. Hal ini juga diperoleh oleh variabel umur administrasi pemerintah daerah yang mana tingkat probabilitas signifikansinya melebihi 0,05 sehingga berarti bahwa umur suatu pemerintah daerah tidak berpengaruh signifikan terhadap tingkat pengungkapan LKPD.

\section{D.2. Pembahasan}

Berdasarkan hasil pengujian di atas diperoleh bahwa terdapat pengaruh secara simultan antara intergovernmental revenue, kekayaan yang dimiliki pemerintah daerah, dan umur pemerintah daerah tersebut dengan tingkat pengungkapan pada LKPD. Sehingga dapat diberi kesimpulan bahwa variabel independen dalam penelitian ini merupakan faktor yang dapat menjelaskan tingkat pengungkapan LKPD. Pengaruh intergovernmental revenue, kekayaan yang dimiliki pemerintah daerah, dan umur pemerintah daerah dapat pula dilihat dari adanya peningkatan pengungkapan LKPD yang dalam satu tahun pengamatan mengalami peningkatan setiap tahunnya, yaitu $54 \%, 58 \%$, dan $60 \%$. Hal tersebut menunjukkan bahwa pemerintah daerah telah memperhatikan pengungkapan pada LKPD. Hasil penelitian ini selaras dengan temuan Setyaningrum \& Syafitri (2012) dan Setyowati (2016).

Berdasarkan hasil uji parsial pada tabel 2 menunjukkan bahwa intergovernmental revenue berpengaruh negatif namun tidak signifikan terhadap tingkat pengungkapan LKPD. Hasil tersebut memberikan makna hubungan intergovernmental revenue dan tingkat pengungkapan pada LKPD berbanding terbalik. Semakin besar intergovernmental revenue yang diperoleh suatu pemerintah daerah, maka semakin sedikit yang akan diungkapkan pemerintah daerah pada laporan keuangannya, khususnya CALK. Hasil ini mengindikasikan bahwa dalam era desentralisasi kontrol khusus dari pemerintah pusat dalam hal penggunaan Dana Perimbangan masih kurang sehingga tidak memotivasi pemerintah daerah untuk meningkatkan pengungkapan pada LKPD.

Hasil penelitian ini diperkuat dengan hasil observasi peneliti di mana pemerintah pusat dan daerah hanya berfokus pada penilaian opini laporan keuangan sehingga tidak berfokus pada pengungkapan LKPD yang dianggap kurang material. Fokus pemerintah lebih diarahkan pada pengelolaan akuntansi dan pengendalian aset daerah yang sering mengalami masalah dan dianggap lebih material. Kompetensi pengelola keuangan yang masih rendah juga menyebabkan tingkat pengungkapan rendah. Hasil penelitian ini sejalan dengan hasil penelitian Setyaningrum \& Syafitri (2012) yang juga menemukan bahwa tingginya tingkat intergovernmental revenue tidak menekan pemerintah daerah untuk mengungkapkan lebih pada LKPD yang disebabkan karena pemerintah pusat kurang memberi kontrol dalam penggunaan dana perimbangan.

Tabel 2 juga menunjukkan bahwa kekayaan yang dimiliki pemerintah daerah tidak berpengaruh signifikan terhadap tingkat pengungkapan LKPD. Hasil penelitian menunjukkan bahwa besarnya kekayaan pemerintah daerah meningkatkan pengungkapan pada LKPD tersebut. Hal tersebut terjadi karena total pendapatan yang diperoleh pemerintah daerah berasal dari Pendapatan Asli Daerah maupun dana transfer dalam hal ini yang dialokasikan oleh pemerintah pusat digunakan oleh pemerintah daerah dalam hal pemenuhan kebutuhan rumah tangga daerahnya, belum untuk upaya dalam meningkatkan pengungkapan pada LKPD. 
Melihat presentase dana transfer dalam hal ini dana perimbangan pemerintah daerah mencapai $80 \%$. Nilai tersebut tergolong cukup tinggi dibandingkan dengan persentase PAD yang hanya $20 \%$ dari total pendapatan daerah. Hal tersebut menunjukkan bahwa tingkat kebergantungan daerah terhadap dana transfer dari pemerintah pusat tergolong tinggi dan pengelolaan PAD masih tergolong rendah. Besarnya tingkat kebergantungan daerah atas dana transfer tidak serta membuat pemerintah daerah meningkatkan pengungkapan LKPD karena pemerintah pusat tidak menekan dan melakukan kontrol khusus dalam hal penggunaan dana transfer. Hasil ini selaras dengan penelitian Khasanah \& Rahardjo (2014) yang mengungkap bahwa kekayaan yang dimiliki pemerintah daerah tidak berdampak terhadap tingkat pengungkapan LKPD karena kepedulian masyarakat atas pajak dan retribusi masih rendah sehingga pemerintah daerah kurang termotivasi untuk mengungkapkan seluruh informasi pada LKPD sesuai dengan SAP.

Penelitian ini juga mengungkap bahwa umur administrasi pemerintah daerah tidak berpengaruh signfikan terhadap tingkat pengungkapan LKPD. Hasil ini menunjukkan bahwa pemerintah daerah yang telah lama dibentuk maupun yang baru dibentuk, tidak berbeda dalam hal tingkat pengungkapan LKPD. Hal ini berarti bahwa pengalaman lama yang dimiliki suatu pemerintah daerah dalam menyusun laporan keuangan tidak berdampak pada tingginya tingkat pengungkapan LKPD tersebut. Hasil ini ditunjukkan dengan temuan bahwa pemerintah daerah yang paling muda di Provinsi Sulawesi Tengah yaitu Kota Palu memiliki rata-rata tingkat pengungkapan LKPD yang lebih tinggi mencapai $75 \%$ dibandingkan pemerintah kabupaten Banggai, Donggala, Poso, dan Toli-Toli yang umumnya berumur lebih tua.

Pemerintah dengan umur yang relative muda dengan sumber daya manusia yang berkompeten akan
Rafida, Ridwan, Abdullah, \& Yamin berbeda dalam hal pengungkapan LKPD dibandingkan pemerintahan dengan umur lebih tua tetapi sumber daya manusianya kurang berkompeten dalam menyusun LKPD. Hasil ini juga ditemukan oleh Laupe (2017) yang diduga disebabkan karena SAP merupakan hal yang relatif baru dan berlaku serentak bagi seluruh pemerintah daerah baik baru didirikan maupun telah lama dididirikan.

\section{E. PENUTUP}

Berdasarkan pembahasan di atas dapat disimpulkan bahwa hanya intergovernmental revenue yang berpengaruh signfikan terhadap tingkat LKPD. Sementara, kekayaan yang dimiliki pemerintah daerah dan umur administrasi pemerintah daerah tidak berpengaruh secara signifikan terhadap tingkat pengungkapan LKPD. Penelitian selanjutnya diharapkan memperluas sampel penelitian dan periode penelitian untuk hasil yang lebih dapat digeneralisasi. Selain itu, penelitian selanjutnya juga dapat menambah variabel independen lain untuk mengembangkan model penelitian.

\section{DAFTAR PUSTAKA}

Armaja. I., R. \& Aliamin. 2015. Pengaruh Kekayaan Daerah, Dana Perimbangan dan Belanja Daerah terhadap Kinerja Keuangan (Studi pada Kabupaten/Kota di Aceh). Jurnal Perspektif Ekonomi Darussalam, 3 (2).

Bastian, Indra. 2010. Akuntansi Sektor Publik: Suatu Pengantar. Penerbit Erlangga: Jakarta.

Halim, Abdul \& Muhammad Syam Kusufi. 2012. Akuntansi Keuangan Daerah. Penerbit Salemba Empat: Jakarta.

Halim, Abdul \& Muhammad Iqbal. 2012. Pengelolaan Keuangan Daerah. UPP STIM YKPN: Yogyakarta.

Hidayanti, Ery \& Sunyoto. 2012. Pentingnya Pengungkapan (Disclosure) Laporan Keuangan 
dalam Meminimalisasi Asimetri Informasi. Jurnal WIGA, 2 (2).

Hilmi, Amiruddin Zul \& Dwi Martani. 2012. Analisis FaktorFaktor yang Mempengaruhi Tingkat Pengungkapan Laporan Keuangan Pemerintah Provinsi. Simposium Nasional Akuntansi $X V$.

Khasanah, Nur Lailatul \& Rahardjo Shiddiq Nur. 2014. Pengaruh Karakteristik, Kompleksitas, dan Temuan Audit terhadap Tingkat Pengungkapan Laporan Keuangan Pemerintah Daerah. Diponegoro Journal of Accounting, 3 (3): 1-11.

Laupe, Supriadi. 2017. Analisis Determinan Tingkat Kepatuhan Pengungkapan Wajib Laporan Keuangan Pemerintah Daerah di Indonesia.

Desertasi

Pascasarjana

Universitas

Tadulako. Palu.

Lesmana, Sigit Indra. 2010. Pengaruh Karakteristik Pemda terhadap Tingkat Pengungkapan Wajib di Indonesia. Tesis Fakultas Ekonomi Universitas Sebelas Maret. Surakarta.

Mahmudi. 2007. Manajemen Kinerja Sektor Publik. UPP STIM YKPN: Yogyakarta.

Mahmudi. 2011. Akuntansi Sektor Publik. UII PRESS: Yogyakarta.

Mardiasmo. 2002. Otonomi \& Manajemen Keuangan Daerah. Penerbit Andi: Yogyakarta.

Mardiasmo. 2009. Akuntansi Sektor Publik. Penerbit Andi: Yogyakarta.

Masdianti, Putu Riesty \& Erawati, Ni Made Adi. 2016. Pengaruh Ukuran Pemerintah Daerah, Kemakmuran, Intergovernmental Revenue, Temuan dan Opini Audit BPK pada Kinerja Keuangan. E-Jurnal Akuntansi Universitas Udayana.

Maulana, Candra \& Bestari Dwi Handayani. 2015. Pengaruh Karakteristik, Kompleksitas Pemerintah dan Temuan Audit Terhadap Tingkat Pengungkapan Wajib LKPD. Accounting Analysis Journal, 4 (1).
Peraturan Pemerintah Republik Indonesia Nomor 71 Tahun 2010 Tentang Standar Akuntansi Pemerintahan.

Ramdhani, Abdullah \& Muhammad Ali Ramdhani. 2017. Konsep Umum Pelaksanaan Kebijaka Publik. Jurnal Publik, 11 (1): 112.

Setyaningrum, Dyah \& Febriyani Syafitri. 2012. Analisis Pengaruh Karakteristik Pemerintah Daerah Terhadap Tingkat Pengungkapan Laporan Keuangan. Jurnal Akuntansi dan Keuangan Indonesia, 9 (2): 154-170.

Setyowati, Lilis. 2016. Determinan yang Mempengaruhi Pengungkapan Laporan Keuangan Pemerintah Daerah. Jurnal Bisnis dan Manajemen, 6 (1).

Suhardjanto, Djoko \& Sigit Indra Lesmana. 2010. Pengaruh Karakteristik Pemerintah Daerah terhadap Tingkat Pengungkapan Wajib di Indonesia. P3M STIE BANK BPD JATENG, 6 (2).

Sutiyoso, Bambang Utoyo. 2009. Kajian Perbandingan Kebijakan Pemerintah Lokal dan Strategi Partisipasi Publik. Jurnal Ilmiah Administrasi Publik dan Pembangunan, 3 (7).

Undang-undang Nomor 32 Tahun 2004 Tentang Pemerintahan Daerah

Waliyyani, Mintotik Ghaniyyu \& Amir Mahmud. 2015. Pengaruh Karakteristik Pemerintah Daerah Terhadap Tingkat Pengungkapan Laporan Keuangan Pemerintah di Indonesia. Accounting Analysis Journal, 2 (1).

Wardjono. 2010. Analisis Faktorfaktor yang Mempengaruhi Price to Book Value dan Implikasinya pada Return Saham (Studi kasus pada perusahaan manufaktur yang terdapat di BEI). Jurnal Dinamika Keuangan dan Perbankan, 2 (1).

Widarjono, Agus. 2007. Ekonometrika: Teori dan Aplikasi untuk Ekonomi dan Bisnis. Edisi Kedua. Ekonisia FE Universitas Islam Indonesia: Yogyakarta. 